\title{
Hubungan Motivasi Perawat Dengan Kepatuhan Pendokumentasian Asuhan Keperawatan
}

\section{Shela Junita Putri}

\section{Shelajunita01@gmail.com}

\section{Latar Belakang}

Mutu asuhan keperawatan dapat tergambar dari dokumentasi proses keperawatan Dokumentasi dalam keperawatan memegang peranan penting terhadap segala macam tuntutan masyarakat yang semakin kritis dan mempengaruhi kesadaran masyarakat akan hak-haknya dari suatu unit kesehatan. Pendokumentasian merupakan suatu kegiatan pencatatan, pelaporan atau merekam suatu kejadian serta aktivitas yang dilakukan dalam bentuk pemberian pelayanan yang dianggap penting dan berharga Pendokumentasian yang tidak dilakukan dengan lengkap dapat menurunkan mutu pelayanan keperawatan karena tidak dapat mengidentifikasi sejauh mana tingkat keberhasilan asuhan keperawatan yang telah diberikan, dalam aspek legal perawat tidak mempunyai bukti tertulis jika klien menuntut ketidakpuasan akan pelayanan keperawatan . Dokumentasi asuhan keperawatan menggunakan pendekatan proses keperawatan yang terdiri dari pengkajian, perumusan diagnosa, perencanaan, pelaksanaan, dan evaluasi sebagai metode ilmiah penyelesaian masalah keperawatan pada pasien untuk meningkatkanpeningkatan pasien Ciri dokumentasi asuhan keperawatan yang baik adalah berdasarkan fakta, akurat, lengkap, ringkas, terorganisir, waktu yang tepat, dan bersifat mudah dibaca Prinsip-prinsip pendokumentasian

Manfaat pentingnya dokumentasi keperawatan adalah dapat digunakan sebagai bukti persidangan, gambaran kinerja pelayanan kesehatan yang diberikan, acuan dalam pendidikan tinggi keperawatan serta merupakan bahan pertimbangan dalam menentukan status pelayanan suatu institusi pelayanan kesehatan. Dokumentasi keperawatan merupakan hal sangat penting, Manfaat pentingnya dokumentasi keperawatan adalah dapat digunakan sebagai bukti persidangan, 
gambaran kinerja pelayanan kesehatan yang diberikan, acuan dalam pendidikan tinggi keperawatan serta merupakan bahan pertimbangan dalam menentukan status pelayanan suatu institusi pelayanan kesehatan

\section{Metode Penelitian}

Metode yang digunakan adalah metode literatur yaitu dengan mengambil data-data melalui buku-buku, situs-situs internet, E-book, jurnal yang terkait dalam penelitian tentang hubungan motivasi perawat dengan kepatuhan pendokumentasian asuhan keperawatan.

Adapun Jurnal yang digunakan dalam penelitian ini dalam kurun waktu diatas tahun 2012 dengan mengambil referensi terkait dengan Hubungan Motivasi Perawat Dengan Kepatuhan Pendokumentasian Asuhan Keperawatan.

\section{Hasil dan Pembahasan}

\section{Hasil}

Dalam kepatuhan perawat dalam peningkatan membuat dokumentasi terdapat faktor faktor yang berpengaruh dalam membuat dokumentasi tersebut ialah umur, umur perawat muda pada umumnya mereka kurang memiliki rasa tanggung jawab, kurang disiplin, sering berpindah-pindah pekerjaan, belum mampu menunjukkan kematangan jiwa, dan belum mampu berpikir rasional. Perawat usia muda masih memerlukan bimbingan dan arahan dalam bersikap disiplin serta ditanamkan rasa tanggung jawab sehingga pemanfaatan usia produktif bisa lebih maksimal

Mayoritas perawat berjenis kelamin wanita maka terlihat bahwa tidak ada proporsi perawat pelaksana dalam pendokumentasian asuhan keperawatan yang baik dan kurang baik sehingga diharapkan teradapat variasi jenis kelamin laki-laki dan perempuan maka pendokumentasian

keperawatan akan lebih baik Perawat dengan tingkat pendidikan yang berbeda mempunyai kualitas dokumentasi yang dikerjakan berbeda pula karena semakin tinggi tingkat pendidikannya maka kemampuan dan 
keterampilan akan meningkat Seorang perawat untuk melakukan analisa memerlukan kemampuan intelektual dan teknik yang memadai. lama kerja turut menentukan kinerja seseorang dalam menjalankan tugas. Semakin lama seseorang bekerja semakin terampil dan semakin cepat dia menyelesaikan tugas tersebut

Program pelatihan sebaiknya diberikan baik pada pegawai baru maupun yang telah ada untuk menghadapi situasisituasi yang berubah. Kualitas pelatihan juga mempengaruhi perawat yang mengikuti pelatihan pendokumentasian. Motivasi kerja yang semakin tinggi menjadikan perawat mempunyai semangat yang tinggi untuk memberikan pelayanan yang terbaik. Hal ini sebanding dengan motivasi untuk melakukan pendokumentasian yang tinggi akan menghasilkan kualitas dokumentasi yang baik. Motivasi merupakan dorongan yang berpengaruh membangkitkan, mengarahkan, dan memelihara perilaku yang berhubungan dengan lingkungan kerja.

\section{Pembahasan}

Seorang perawat dalam melakukan pelayanan keperawatan profesional, tentu tidak terlepas dari motivasi kerja yang tinggi agar mempunyai semangat dalam bekerja sehingga mampu meningkatkan kinerja yang akan berdampak langsung terhadap mutu dan kepuasan klien. perawat dalam melakukan pelayanan keperawatan profesional, tentu tidak terlepas dari motivasi kerja yang tinggi agar mempunyai semangat dalam bekerja sehingga mampu meningkatkan kinerja yang akan berdampak langsung terhadap mutu dan kepuasan klien.

Dalam pengambilan dokumentasi, perawat dapat mendokumentasi terdapat hal hal yang dapat membuat perawat tersebut patuh dalam mendokumentasikan dapat dipengaruhi oleh berbagai factor diantaranya adalah pengetahuan dan kompetensi perawat Pengetahuan dan kompetensi perawat sangat dipengaruhi oleh tingkat pendidikannya.Selain itu sistem pendokumentasian juga dapat dipengaruhi oleh beban kerja yang tinggi. Kemampuan menangani beban kerja ini dapat dipengaruhi oleh jenis kelamin juga. 
Seorang perawat dalam melakukan pelayanan keperawatan profesional, tentu tidak terlepas dari motivasi kerja yang tinggi agar mempunyai semangat dalam bekerja sehingga mampu meningkatkan kinerja yang akan berdampak langsung terhadap mutu dan kepuasan klien. Hal ini dapat dilihat bahwa seorang perawat yang memiliki tingkat kerja yang tinggi akan selalu mendokumentasikan tentang apa saja yang dilakukan perawat tersebut.

Karakteristik dalam pengambilan dokumentasi terdapat factor factor yang dapat mempengaruhi pengambilan dokumentasi seperti umur, jenis kelamin, tingkat pendidikan, masa kerja dan pelatihan. Motivasi kerja yang semakin tinggi menjadikan perawat mempunyai semangat yang tinggi untuk memberikan pelayanan yang terbaik. Hal ini dapat diketahui dengan motivasi untuk melakukan pendokumentasian yang tinggi akan menghasilkan kualitas dokumentasi yang baik.

Pengawasan yang dilakukan oleh atasan sebenarnya harus dilakukan demi meningkatkanya dokumentasi yang dibuat oleh perawat terebut, dan dorongan motivasi oleh atasn tersebut dapat membuat perawat tersebut semakin giat dalam mendokumentasikan sesuatu yang dikerjakan oleh perawat tersebut. Adapun manfaat dokumentasi keperawatan adalah sebagai bentuk pembuktian kepada pihak pasien maupun rumah sakit,sebagai alat komunikasi, agar mengetahui perkembangan pasien.

Selain itu sistem pendokumentasian juga dapat dipengaruhi oleh beban kerja yang tinggi. Kemampuan menangani beban kerja ini dapat dipengaruhi oleh jenis kelamin. Apabila perawat yang memiliki jiwa tinggi dalam pekerjaan nya maka dokumentasi yang telah dibuat akan ada setiap aat, dan apabila perawat yang tidak memiliki nilai juang tinggi dalam pekerjaannya maka setiap yang dilakukan maupun yang terdapat pada pasien tidak akan didokumentasikan.

Pendokumentasian dibutuhkan motivasi dari hati oleh perawat tersebut, karena dalam pendokumentasian diperlukan kesadaran diri oleh perawat tersebut. Pendokumentasian yang dilakukan oleh perawat adalah aktifitas yang sangat penting 
karena itu adalah bentuk pelayanan terhadap pasien pasien agar mengetahui tntang apa yang dikerjakan.

Pendokumentasian merupakan suatu kegiatan pencatatan, pelaporan ataumerekam suatu kejadian serta aktivitas yangdilakukan dalam bentuk pemberianpelayanan yang dianggap penting dan berharga. Pendokumentasian yang tidak dilakukan dengan lengkap dapat menurunkan mutu pelayanan keperawatan karena tidak dapat mengidentifikasi sejauh mana tingkat keberhasilan asuhan keperawatan yang telah diberikan, dalam aspek legal perawat tidak mempunyai bukti tertulis jika klien menuntut ketidakpuasan akan pelayanan keperawatan. Dokumentasi asuhan keperawatan menggunakan pendekatan proses keperawatan yang terdiri dari pengkajian, mendiagnosa, perencanaan, pelaksanaan, dan evaluasi.

Umur juga yang muda juga perawat yang berusia muda pada umumnya mereka kurang memiliki rasa tanggung jawab, kurang disiplin, sering berpindahpindah pekerjaan, belum mampu menunjukkan kematangan jiwa, dan belum mampu berpikir rasional. Perawat usia muda masih memerlukan bimbingan dan arahan dalam bersikap disiplin serta ditanamkan rasa tanggung jawab sehingga pemanfaatan usia produktif bisa lebih maksimal. Maka dari itu peraawat yang berusia muda seharusnya lebih melhat perawat-perawat yang berpengalaman dala hal mendokumenasikan. Sehingga perawat muda tersebut dapat mengetahui pentingnya dalam dokumentasi.

Motivasi sangat berpengaruh terhadap kinerja seorang perawat dikarenakan, karena motivasi dapat membuat seorang perawat lebih menambah kinerjanya, sehingga pelayanan seorang perawat terhadap pasiennya lebih bagus. Seseorang yang memiliiki kinerja tinggi lebih dapat membuat kualitas ruah sakit tersebut lebih dikenal pasien.

\section{Penutup}

Motivasi perawat dalam mendokumentasikan asupan keperawatan tergantung pada factor-faktor yang mempengaruhi seperti : umur, pendidikan, lama bekerja dan nilai yang tinggi terhadap pelayanan. Maka dari itu perawat yang 
mendokumentasikan setiap asupan keperawatan tergantung dari nilai juang perawat tersebut. Dan terdapat hubungan motivasi perawat dengan kepatuhan pendokumentasian terhadap keperawatan.

\section{Daftar Pustaka}

Renny, N, G., Octava, G., \& Peekie, R. (2018). Hubungan Motivasi Perawat Dengan Kepatuhan Pendokumentasian Asuhan Keperawatan Di Ruangan Perawat Penyakit Dalam RSUD Noongan. E-jurnal Sariputra. 5 (1). 10-15.

Riska, W. (2016). Motivasi Perawat Dalam Pelaksanaan Pendokumentasian Asuhan Keperawatan. Jurnal Kesehatan Holistik. 10 (2). 61-66.

Tutik, A., Chikita, A, M. (2019). Hubungan Motivasi Kerja Dan Imbalan Yang Di Terima Perawat Dalam Kepatuhan Pendokumentasian Flowsheet. Jurnal Ilmiah Kesehatan Pencerah. 8 (1). 67-74

Retyaningsih, I, Y., Bambang, E, W. (2013). Hubungan Karakteristik Perawat, Motivasi, Dan Supervisi Dengan Kualitas Dokumentasi Proses Asuhan Keperawatan. Jurnal Managemen Keperawatan. 1 (2). 107-114

Bara, M., Suryanti, B. (2014). Hubungan Motivasi Perawat Dengan Pelaksanaan Pendokumentasian Asuhan Keperawatan Di Ruang Rawat Inap RSUD Pasar Rebo. Jurnal Health Quality. 5 (1). 9-19.

Rainol, S., Ngesti, W, U., \& Novita, D. (2018). Hubungan Motivasi Kerja Perawat Dengan Sistem Pendokumentasian Asuhan Keperawatan Di Rumah Sakit Islam UNISMA Kota Malang. Nursing news. 3 (3). 452-458.

Malihah, R, R. (2019). Faktor-faktor Yang Mempengaruhi Kepatuhan Perawat Dalam Pendokumentasian Asuhan Keperawatan. Jurnal Ilmiah Kesehatan. 18 (1). 49. 
Supratti \& Ashriady. (2016). Pendokumentasian Standar Asuhan Keperawatan Di Rumah Sakit Umum Daerah Mamuju Indonesia. Jurnal Kesehatan Manarang. 2 (1). 44-51.

Ashriady., \& Supratti. (2016). Pendokumentasian Standar Asuhan

Keperawatan Di Rumah Sakit Umum Daerah Mamuju, Indonesia. Jurnal Kesehatan MANARANG. 2(1), 44-51.

Mastini, P., Suryadhi, N, T., \& Suryani, A. (2015). Hubungan Tingkat Pengetahuan, Sikap, Beban Kerja Perawat Dengan Pendokumentasian Asuhan Keperawatan Di IRNA IGD RSUP Sanglah Denpasar. Public Health and Preventive Medicine Archive. 3 (1). 49-53.

Simamora, R. (2009). Dokumentasi Proses Keperawatan.

Simamora, R. H., Purba, J. M., Bukit, E. K., \& Nurbaiti, N. (2019). Penguatan Peran Perawat Dalam Pelaksanaan Asuhan Keperawatan Melalui Pelatihan Layanan Prima. JPPM (Jurnal Pengabdian Dan Pemberdayaan Masyarakat), 3(1), 25-31. 